\title{
Normative Beliefs about Money in Families: Balancing Togetherness, Autonomy, and Equality
}

\author{
ABSTRACT \\ Using original data from a nationally representative vignette-survey experiment $(n=3,986)$, \\ this study investigated norms about income sharing within families. Respondents were asked to \\ select a preferred income allocation strategy for a fictional couple with varied circumstances. \\ Findings showed that despite differences in fictional couples' marital and parental statuses, the \\ majority of respondents indicated all couples should ideally pursue some level of autonomy \\ within their relationships. Respondents also believed higher-earning partners ought to hold back \\ a greater absolute value of their income, potentially reproducing unequal labor market conditions \\ within families. When women were presented as the primary earner, the ideal level of \\ withholding income was slightly larger in magnitude than when men were shown as the primary \\ earner. Findings challenge the notion that marriage distinctively establishes a unitary family \\ interest and suggest normative support for women's self-determination in lieu of a push for \\ gender equality.
}


Money in Families

\section{INTRODUCTION}

Through the mid-19th century, cultural and structural forces consigned wives' earnings to their husbands. Thereafter, couples gradually began to replace male-controlled allocation methods with joint accounts and a steady stream of court decisions and state laws progressively granted women more economic rights in the United States (Zelizer, 1989). Further social and demographic changes — such as increasing participation of married women in the labor force, rising divorce rates, an expansion of cohabitation, and delayed marriages (Bumpass \& Lu, 2000; Spain \& Bianchi, 1996)—resulted in relationship expectations becoming de-standardized and financial arrangements becoming more dependent on individual negotiations (Burgoyne, 2008; Kenney, 2006). Today, couples are more likely to withhold money from a common pot than they were a generation ago (Knudsen \& Wærness, 2009; Pahl, 2005). Increases in keeping some or all money separate has generated competing claims about what the pattern symbolizes: a rise in the instability of families (Brines \& Joyner, 1999; Burgoyne, Reibstein, Edmonds, \& Routh, 2010; Vogler, 2005), a shift towards individualized marriages (Lauer \& Yodanis, 2011; Yodanis \& Lauer, 2014), or evidence of movement towards an ethos of gender equality (Elizabeth, 2001; Vogler, Brockmann, \& Wiggins, 2008).

In the absence of empirical investigation, we don't know the reasoning behind the ways income is allocated within families. This article makes an important methodological contribution to the literature by using a vignette-survey design to investigate normative beliefs about how income is ideally distributed between partners. An extensive body of research examining the distribution of money in households has relied on survey measures and qualitative interviews (Bennett, 2013). Early researchers focused on grouping systems of money arrangements into analytical categories (Ashby \& Burgoyne, 2008; Pahl, 1995). Thereafter, many have searched for 
possible explanations for the prevalence of various categories and sought to identify the consequences of these arrangements (Bennett, 2013). To the author's knowledge, this study is the first to use an experimental survey design to evaluate normative beliefs about the allocation of financial resources within American families.

Illuminating popular attitudes about the distribution of money in families is essential for understanding motivations of behavior, as individuals draw on shared cultural knowledge to organize their expectations of their partners and make plans for their future (Ridgeway, 2011; Vaisey, 2009). For example, when Barlow (2008) presented vignettes to interview participants in England and Wales, she found that beliefs about legal protection for cohabiting couples was out of sync with legal realities. The vignette experiment design is advantageous for studying norms because what people report about other people's families may reflect cultural values more than their own family behavior does, as the latter reflects a mixture of attitudes, circumstance, and other factors (Cherlin, 2009). Analyses of behavioral practices may be less indicative of changing norms than analyses of what people think others should do because couples' financial practices are generally unchanging, their behaviors potentially lagging indicators of current cultural beliefs (Bisdee, Daly, \& Price, 2013). A vignette experiment approach overcomes some of the difficulties embedded in surveys of behavior, such as teasing apart behaviors that were adopted with purpose and those that are taken on because of convenience or as a result of temporary or unexpected circumstances (Addo, 2017; Treas, 1993). Furthermore, a nationally representative survey is a feasible option, while obtaining that kind of sample can be a challenge for qualitative interviewing.

This article also addresses a secondary limitation in the existing research on the allocation of money in families. Prior studies generally disregarded the gradations of response categories 
"keeping some money separate" and "keeping all money separate," preferring instead to study a dichotomous difference of "pooling all money" or "not pooling all money" (see Hamplová and Le Bourdais, 2009 for an exception). Focusing on variations is important to understanding the crossroads between the family domain's emphasis on interdependence and the market domain's emphasis on self-reliance (Bellah, Madsen, Sullivan, Swidler, \& Tipton, 2008; Yodanis \& Lauer, 2014). Pooling some, but not all, money may be an increasingly preferred arrangement for couples because it facilitates the redistribution of income, while simultaneously allowing continued control over some individual money. Emerging research suggests a range of separate and collective income distribution arrangements exist on a continum, all of which warrant careful interpretation (Ashby \& Burgoyne, 2009; Burgoyne, 2008). This article contributes to the literature by considering shades of financial separateness and togetherness, important to understanding normative beliefs about money in families. In addition to treating partial-pooling as a separate allocation strategy from sharing resources or keeping resources separate, this research also investigates the preferred scale of pooling and separation.

The unresolved transformation of families and the ongoing gender revolution provide an optimal climate to consider how competing cultural values shape behavior (Swidler, 1986). Two contradictory values related to the distribution of money within intimate relationships are most commonly studied: 1) the conflict between couples' commitment to their collective units and their desires for individual autonomy, and 2) the struggle to create equal partnerships given inequalities prevalent in the labor market (Blumstein \& Schwartz, 1983; Burgoyne, 1990; Pahl, 1989; Treas, 1993; Vogler et al., 2008). In this paper, I consider these contradictions in relationship to each other, exploring the ways the first contradiction operates within a cultural context in which gender equality is pursued but nevertheless remains incomplete. Below, I 
develop predictions about normative beliefs regarding the allocation of money within various fictional families. I then describe the original vignette-survey experiment, present data collected from a nationally representative sample of U.S. adults, and discuss the findings.

\section{BACKGROUND}

\section{Disintegration and Family Stability}

The original purpose of marriage was to integrate resources (Coontz, 2005). Conventional notions of married couples assume unitary interests, where financial resources are conceptualized as shared and allocated equitably among family members (Catlett \& McKenry, 1996). Couples' integration of resources is thought to be influenced in part by expectations of the longevity of the relationship and by the legal protections provided to married couples, which is an explanation for the higher integration levels of married couples compared with cohabitors (Burgoyne et al., 2010; Desai, 1992; Treas, 1993). Couples who have low relationship satisfaction are presumed to refrain from investing in the relationship, instead maintaining independent management of their money, leaving open the ability to exit the partnership (Burgoyne, Clarke, Reibstein, \& Edmunds, 2006; Kamp Dush, 2011; Kenney, 2006; Treas, 1993). Evidence suggests that the lack of a joint bank account is both a reflection of and a source of lower relationship quality (Addo \& Sassler, 2010; Oropesa \& Landale, 2005). Consequently, the increasing tendency of couples to withhold money from a common pot could be indicative of rising instability in family relationships (Brines \& Joyner, 1999; Burgoyne et al., 2010). If increases in withholding money from shared administration stem from rising instability in family relationships, couples viewed as most stable should be evaluated as ideally integrating their resources. Thus, couples who have greater relationship investments, such as a public marriage commitment, long relationship durations, or children together are expected to be evaluated as ideally adopting collectivist 
money arrangements. Relationship duration may influence perceptions of integration to a greater extent for cohabiting couples or for couples who are not parents.

The heterogeneity of cohabiting couples makes predictions about perceptions of cohabitors' financial behaviors challenging. Three key complications arise when considering perceptions of cohabiting couples' financial arrangements. First, about two-thirds of marriages are preceded by cohabitation (Manning, 2013). Cohabiting couples planning to marry are more likely to integrate their finances while living together compared with cohabitors without intentions to legally wed (Addo, 2017). Rather than being viewed as less committed than married couples, cohabitors may be interpreted as either taking a step towards marriage or seeking a replacement for marriage altogether. Therefore, evaluation of cohabiting couples' finances may parallel married couples.

Second, behavioral evidence reveals parents act more alike than non-parents, no matter their marital status (Barlow, 2008; Kenney, 2004; Lyngstad, Noack, \& Tufte, 2011; Vogler et al., 2008). A majority of nonmarital births now occur in cohabiting unions and for all but the most advantaged women, parenthood has been decoupled from marriage (Lundberg \& Pollak, 2014). Parenthood may be the key family transition in which people consider financial togetherness to be appropriate (Barlow, 2008). It remains unclear if cohabiting parents' in the United States integrate finances because of similar beliefs in family togetherness at the time co-parenting begins or whether joining finances reflects practical considerations, such as protecting against financial hardships (Addo, 2014). It is an open empirical question whether the effects of marital and parental status are additive - that is, are married parents seen as having the most stable relationship?

Third, differential selection of couples into marriage is challenging to isolate from behavioral differences which develop from marital status influences. Although cohabitation is 
common for all education levels and racial-ethnic groups (Bumpass \& Lu, 2000; Smock, 2000), marriage is more common among the most advantaged couples - those with a college degree, higher income levels, and for White couples (Gibson-Davis, Edin, \& McLanahan, 2005; Goldstein \& Kenney, 2001; Schoen \& Cheng, 2006). The majority of cohabitors are younger than 35 years old, making generational differences important considerations (Stepler, 2017). Cohabitation may be less likely to be a pathway to marriage for Black and low income couples compared with more advantaged couples because of the economic disadvantages these couples confront (Edin \& Nelson, 2013; Manning \& Smock, 2002). On the one hand, couples who differ by educational attainment, income and other demographic characteristics could share similar goals for family togetherness and separateness, and the variations in behavior may be attributed to differences in resources and risk exposure to financial hardships (Romo, 2014). If this is the case, I would expect to see similar perceptions of ideal financial arrangements for fictional couples across demographic groups, despite the behavioral differences documented in the prior literature (Kenney, 2004). On the other hand, the disparities couples confront could result in dissimilar beliefs about what is best for couples. Given this proposition, variations in ideal financial arrangements would be expected to vary systematically by respondents' characteristics. Individualized Relationships and Economic Autonomy

Increases in keeping some money for individual use may be symbolic of the cultural transition to "individualized marriages" rather than a symptom of family instability. As the importance of marriage as a public institution diminishes, widespread individualist interests supposedly lead couples to keep their finances separate (Treas \& Widmer, 2000). According to this scholarship stream, marriage transformed in the 1960s and 1970s from a community-focused institution to a conduit for self-development (Cherlin, 2004). In individualized marriages, each 
person maintains their individuality, more or less refraining from interdependence, and the relationship is maintained so long as it is fulfilling and emotionally supportive for both parties (Cherlin, 2004, 2009). Cross-cultural analyses show that couples with individualized conceptions of relationships are less likely to integrate their financial resources (Lauer \& Yodanis, 2011).

Although the marriage contract requires financial support of spouses and treatment of the family as a single economic unit, people earn money in the labor market as individuals (Burgoyne, 1990; Burgoyne \& Lewis, 1994; Nyman \& Reinikainen, 2007). Additionally, with later transitions into marriage, people bring their own bank accounts, debt, and financial habits into their new family units. Some people place conditions on the assumption of automatic joint ownership imposed by marital laws (Barlow, 2008). Even when income is thought of as a collective resource (and is enforceable legally in the case of marriage), partners remain cognizant of how money is earned and engage in mental accounting — earmarking and distinguishing between different kinds of money (Burgoyne, 1990; Burgoyne et al., 2006; Burgoyne \& Lewis, 1994). Thus, ideals of married couples fully sharing financial resources may not be universal or even overwhelmingly endorsed today. It is also possible that families seen as highly unified (i.e., married parents) will elicit beliefs about rights to individual earnings at lower levels compared with couples viewed as less unified. Income is legally a collective resource for married couples and parenting may signal a long-term, unitary interest. Together, these variations may dilute perceptions about the entitlement to individually owned money in committed partnerships.

A related tenet of the transition to individualized marriages is that marriage may be one option among many relationship forms (Cherlin, 2004; Lauer \& Yodanis, 2011). Changing family law, such as the introduction of no-fault divorce, changes expectations about the permanency of marital relationships, potentially diminishing distinctions between commitments 
made by cohabitors and those made by couples who marry (Lundberg \& Pollak, 2014). Although cohabiting couples typically either terminate their relationship or marry within three years, some couples cohabitate for long durations without an intention to marry (Bumpass \& Lu, 2000;

Goodwin, Mosher, \& Chandra, 2010; Manning \& Smock, 2002). Married couples share financial resources in part to minimize transaction costs, such as the need to negotiate and monitor the use of funds (Oropesa, Landale, \& Kenkre, 2003; Treas, 1993), and cohabitors may also do the same, as they spend longer durations living together unmarried. Therefore, if marriage is seen as one relationship option among many, cohabiting couples may be viewed as ideally integrating some financial resources as a way to decrease transaction costs, similarly to married couples.

\section{Unequal Markets and Gender Equality}

Much like the tension between family unity and individual autonomy, couples attempt to resolve any discordance between beliefs in equal partnerships and in entitlement to individual ownership of income earned in the labor market, even when market rewards are unequal (Bennett, 2013; Elizabeth, 2001). Resource and exchange theories have driven much of the scholarly literature on power within marriages, explaining men's family power as a function of their greater monetary contribution to the household (Coltrane, 1996; Ferree, 1990). Higherearning individuals in couples, overwhelmingly men, tend to have the last word about family financial decisions and more often spend ostensibly shared money without consulting their partners (Burgoyne et al., 2006). Higher earners tend to hold power even over decisions having little to do with money, such as choosing shared leisure activities (Blumstein \& Schwartz, 1983; Schwartz, 1994). Many men talk about bonuses as their own money, not necessarily deposited into the shared family pot (Zelizer, 1989). When income is seen as a personal asset and couples 
are viewed as preferably maintaining some individual control over income, higher earners may be evaluated as having greater entitlement to personal earnings.

I also offer two competing predictions about the gendered nature of support for economic autonomy. Extant research documents women's challenges in gaining greater power within the family despite their increased financial contributions, and expectations for men to contribute financially to the common pot remain strong (Townsend, 2002). An acceptance of women in the labor force does not necessarily translate into all couples desiring equal financial partnerships, as some couples prefer men to be the primary earner (Bertrand, Kamenica, \& Pan, 2015; Milkie, Bianchi, Mattingly, \& Robinson, 2002). Women's earnings tend to be treated differently than men's earnings, earmarked for childcare and housekeeping expenses (Burgoyne, 1990; Zelizer, 1989). Women's discretionary spending is often contingent on the family's budget needs, whereas men seem to pay themselves first (Tichenor, 1999). Given that primary earning wives do not translate their higher-earning status into power to the same extent as men (Blood \& Wolfe, 1960; Blumstein \& Schwartz, 1983; Burgoyne, 2004; Burgoyne et al., 2006; Hochschild \& Machung, 1989), women's higher relative earnings may be insufficient to elicit agreement that they are entitled to more personal spending money. Therefore, perceptions of economic autonomy may be more common when men are presented as earning more than when women are shown to be the higher relative earner. Perceptions of economic autonomy may also be conditional on marital and parental status, as conventional marriage combines ideals of male dominance with male breadwinning (Blumstein \& Schwartz, 1983; Townsend, 2002).

Alternatively, women have made some progress in converting their earnings into power. Women have gained influence in family decision making and increased control of family money as the difference in their income relative to men has diminished (Belch \& Willis, 2002; Kenney, 
2006). Despite the challenges to achieving equal partnerships, most couples express a desire for equality in their relationships (Gerson, 2009; Pedulla \& Thébaud, 2015). Modern couples may withhold money as a tactic to ensure each person has access and control over some money (Elizabeth, 2001). In partnerships where a woman's income is sufficient to support herself and the male partner holds less conventional beliefs about gender, couples are more likely to take a partial-pooling approach, combining some but not all of their earnings (Vogler, Brockmann, \& Wiggins, 2006). Analysis of same-sex couples showed these couples also tended to keep at least some money separate as a way to facilitate equality within their relationships (Burns, Burgoyne, \& Clarke, 2008). Women may be viewed as ideally keeping their earnings in a personal rather than shared account as a means of ensuring women's continued control over their finances, given the realities of persistent gender inequality in the marketplace. In other words, the mechanism for achieving fairness in relationships may be dependent on the gender of the earner. Men's higher earnings may not elicit a similar need to withhold income from a shared account as a tactic for men to maintain power over their earnings. But when women are shown as the higher earner, respondents may believe women should withhold money from the common pot in order to maintain control over some household money.

\section{DATA AND METHODS}

\section{Data and Experimental Design}

I used original data from a nationally representative dataset obtained through GfK, funded by Time-sharing Experiments for the Social Sciences (http://www.tessexperiments.org) (Freese \& Druckman, 2016). Respondents were recruited by GfK using probability-based sampling of U.S. addresses and were provided with equipment for internet access, if needed, to participate. This study was fielded in July and August 2016 on a random sub-set of GfK panelists, resulting 
in a total sample size of 4,020 respondents. Thirty-one respondents failed to answer the primary question of interest for the analysis and three respondents selected a partial-pooling approach for the fictional couple, but in a follow-up question divided the earnings into an all-individual or an all-shared approach. These respondents were dropped from the analyses for a total analytic sample size of 3,986 respondents.

Respondents were asked to evaluate the income organizing strategies of couples in fictional vignettes. The vignette design used a two-by-two-by-two-by-three factorial design, resulting in 24 different vignettes (summarized in Figure 1). The fictional couple differed by marital and parental status, relationship duration, and relative earnings. Roughly equal numbers of respondents (315-348 respondents) viewed each of the 24 vignettes. Respondents were told that they would view a hypothetical scenario and be asked to give their opinion of how a couple should handle money. For example, the married parents, three-year relationship duration, man as primary earner vignette is shown here (italics show vignette manipulation):

Michelle and Anthony, both 31 years old, are married and have been a couple for 3 years. They enjoy spending time together and they are happy with their relationship. They have one child together. Although they both work about forty hours per week, Anthony earns \$2,800 a month while Michelle earns \$1,200 a month.

I manipulated the marital and parental status to test perceptions of family togetherness. The relationship duration in the vignette was manipulated to adjust for influences related to the longevity of the relationship. The fictional couple was presented as being together for either three or seven years. The three-year duration represents the point in the life course of relationships that was expected to elicit the greatest perception of differences in family unity between cohabiting and married couples while still conveying some level of stability. Adding the seven-year relationship duration to the vignette tested this assumption while allowing the presented ages of the couple to continue to be believable. The total household earnings were 
based on analysis of median total household income $(\$ 53,657)$ calculated from the 2014 American Community Survey (DeNavas-Walt \& Proctor, 2015). This estimate was rounded down to make comparisons of earnings more interpretable for respondents and to represent the lower earner as making just over the federal minimum wage. The gap between the man's share and the woman's share of the family's earned income was manipulated to show either a primary earner or an equal earning scenario. By varying whether the primary earner was a man or woman, I tested whether beliefs in economic autonomy were conditional on gender.

[Insert Figure 1 about here]

To address potentially confounding variables, other characteristics of the hypothetical couple were indicated and held constant across all vignettes. Couples were presented as both working 40 hours a week, the most common employment arrangement for couples in which both are employed and as a way to hold constant the hours spent in paid labor for each partner. The couple was also described as 31 years of age, slightly above the average age of marriage and the average age for first births (Cohen, 2014). This age is advantageous for comparing first marriages and cohabitation, theoretically important to understanding demographic trends in family formations (Cherlin, 2009). This age is also less encumbered with potentially unintended assumptions related to later life stages (e.g., likelihood of prior investments, approaching retirement, probability of remarriage, obligations to children from previous relationships, financial support to aging parents). Racially neutral names, Anthony and Michelle, were selected by choosing the most popular shared names for Black and White babies born in this age range (Lieberson, 2000). Pilot tests of the vignette showed most respondents assumed the couple's racial identity was either White or the same as their own race. 
Money in Families

\section{Dependent Variables}

There are two dependent variables in this analyses. First, I used evaluations of bank account ownership as a measure of how income should be distributed between partners. This measure was adapted from behavioral indicators of how couples organize their finances, which is used in surveys such as the International Social Survey Program, Fragile Families and Child Wellbeing Study, and the National Longitudinal Study of Adolescent Health (Brooks-Gunn, Garfinkel, McLanahan, \& Paxson, 2011; Harris et al., 2009; ISSP Research Group, 2014). After presenting the hypothetical couple, respondents were informed that couples organize their income in many different ways and then asked, "Do you think Michelle and Anthony should: (a) Have a shared account in which they both deposit all their earned income; (b) Keep all their earned income in separate, individual accounts; or (c) Have both a shared account and separate, individual accounts?" Selection of a shared account was used as an indicator of a unitary family interest, as both individuals in the couple are expected to deposit their income into this account and all expenses, joint and individual, will thus be withdrawn from this account. Selecting answer choice (b) — in which each person should have their own individual accounts and no joint account — indicated that money was perceived to be an individualized resource, as earnings remain individually accessed and controlled and the couple consists of two separate financial entities. Respondents who selected option (c), having both a shared and individual account, are subsequently referred to as selecting the "partial-pooling" option. Thus, this dependent variable includes three categories: shared account, separate account, and both accounts.

The second dependent variable concerns the respondents who selected the partial-pooling option. These respondents were asked to determine how much money Michelle and Anthony should each put in their individual accounts and in a shared account. The survey required the 
total amounts to be summed to the manipulated income presented for each person in the vignette. Therefore, this dependent variable is continous. I transformed the dependent variable from the dollar amounts allocated into each account (e.g., his, hers, and shared) into proportions of the total household income so that the denominator $(\$ 4,000)$ was held steady across the relative earnings manipulations. Because this dependent variable was transformed into a proportion, in addition to the analyses presented in this article, I also estimated a generalized linear model with the logit link and the binomial family. Comparisons of the models showed the conclusions presented here remain the same, regardless of the model.

\section{Predictor Variables}

The primary predictor variables of interest are the categorical vignette conditions: marital and parental status, relationship duration, and relative earnings. I combined the vignette couple's marital and parental status to allow for simultaneous evaluation of whether respondents treat cohabitation as a similar condition to marriage and whether parental status influences this comparison, which results in four possible categories: cohabiting non-parents, cohabiting parents, married non-parents, and married parents. The relationship duration is a dichotomous variable (three years or five years). The relative earnings variable includes three categories: man primary earner, equal earners, and woman primary earner. For all analyses, the cohabiting nonparents, together for three years with the man primary earner, serves as the reference category.

Respondents were randomly assigned to a vignette condition, so demographic controls are not necessary in the statistical models (Maxwell \& Delaney, 2004; Mutz, 2011). Nevertheless, for theoretical reasons, demographic differences in normative beliefs are important to the analyses. I therefore included predictor variables that prior literature suggests are associated with behavioral differences in the ways people report organizing income within families. These 
include gender (Pahl, 1995), marital status (Burgoyne \& Morison, 1997), parental status (Lyngstad et al., 2011), age (Vogler \& Pahl, 1994), race-ethnicity (Addo \& Sassler, 2010; Kenney, 2004), education (Treas, 1993), employment status (Kenney, 2006), and income (Copp, Giordano, Manning, \& Longmore, 2016). Table 1 shows the descriptive statistics for the sample. [Insert Table 1 here]

\section{Analyses}

First, I used multinomial logistic regression, selected because the first dependent measure is nominal and contains more than two categories (i.e., shared, separate, partial-pooling). In analysis not shown, the Wald test for combining alternatives revealed that each of the three income organizational approaches were distinct categories. Additionally, the Hausman test showed the model does not violate the independence of irrelevant alternatives assumption (Hausman \& McFadden, 1984). I discuss the effects of the vignette manipulations on selecting an allocation strategy for the fictional couple first and then discuss differences by the respondents' own demographics.

Second, for the sub-sample of respondents who selected the partial-pooling option, I estimated ordinary least squares regression models to evaluate differences in the amount of income distributed between shared use and individual accounts. To ease interpretation of the results, I estimated the predicted percentages of the total household income to be deposited in his, her, and their shared accounts from ordinary least squares regression models. All results are presented using the analytical weights, and in analyses not shown, the results remained the same when modeled without the weights.

\section{RESULTS}


Table 2 shows the weighted descriptive statistics for the two dependent variables. The most commonly selected organizational approach was the partial-pooling option. Between $40 \%$ and $50 \%$ of respondents selected this option across each of the vignette manipulations. Respondents were more likely to select a shared-only approach when the ficitional couple was presented as a married couple $(48 \%)$ or parents $(42 \%)$ compared with a cohabiting couple $(30 \%)$ and when the couple was shown as child free $(37 \%)$. The bivarite statistics show the type of organizational approach did not seem to vary by the relative earnings of the fictional couple. When the partialpooling approach was selected, across all vignette manipulations, respondents indicated on average that about $60 \%$ of the couple's total household income should be shared. Respondents' reports of distribution into individual accounts did not seem to vary by the marital or parental status of the vignette couple. When the woman was shown as the primary earner, respondents reported $33 \%$ of the total household income should be kept in her account compared with $13 \%$ when she was the lower earner and $20 \%$ when the couple was shown as equal earners. A similar pattern held for respondents' views of deposits into the fictional man's account.

[Insert Table 2 here]

As seen in Table 3, results from the multinomial logistic regression revealed the marital and parental status of the vignette couple was statistically significantly associated with the chosen organizational approach selected by respondents. Compared with cohabiting couples without children, respondents were less likely to select either separate accounts or a partial-pooling option for all other couples. These differences were statistically significant across marital and parental comparisons, with the exception of selecting a partial-pooling option, which was similar for cohabitors regardless of whether they were presented as parents. When the couple was presented as together for seven years compared with three years, respondents were less likely to 
select the separate accounts only option but there were no statistical differences by relationship duration and selecting a pooling or a partial-pooling approach. Interactions of relationship duration with marital and parental status (results not shown) were minimal. Only for cohabitors together for three years compared with married couples together for seven years did respondents select partial-pooling arrangements to a greater extent than a shared-only account. The relative earnings vignette manipulation did little to predict the type of account selected. Only when couples were shown as equal earners were respondents more likely to believe the couple should have both individual and separate accounts compared with only a shared account.

Turning now to the respondents' characteristics, the findings show some differences in normative beliefs across demographic groups. Compared with married respondents, all other respondents were more likely to select a separate-only or partial-pooling approach for the fictional couple. Consistent with behavioral research, people of color and those with lower incomes were less likely to select a pooling-only approach, compared with White respondents and those with higher incomes. Employed and college-educated respondents were more likely to select a partial-pooling approach than a pooling-only approach compared with unemployed and less educated respondents. These results are consistent with predictions that normative beliefs about money vary systematically by respondents' characteristics.

\section{[Insert Table 3 here]}

For ease of interpretation, the predicted probability of selecting each organizational approach is presented in Figure 2, holding other model variables at their means. Tests of the difference in predicted probability of selecting each category are notated in Figure 2. Statistical tests were adjusted for the multiple comparisons using the Bonferroni adjustment, dividing the alpha level $(\mathrm{p}=.05)$ by the number of pairwise tests $(6)$. As expected, the predicted probability 
of reporting the couple should have only separate accounts was most likely when the couple was presented as cohabiting without children (.31) compared with the other three groups $(\mathrm{p}<.008)$. The predicted probability of selecting only a shared account was higher for married couples with and without children, about .48 , compared with cohabiting couples (.25 without children and .34 for parents). Parental status had an independent effect on ideals of financial integration for cohabiting couples, as being presented with a parenting vignette was associated with a .09 higher probability of selecting only a shared account $(\mathrm{p}<.008)$. There were no statistically significant differences between evaluations of married couples by parental status.

[Insert Figure 2 about here]

The predicted probability of selecting the partial-pooling option was greater for cohabiting couples compared with married couples. Sixty-nine percent of respondents ( .25 shared-only plus .44 partial-pooling) would be predicted to select some level of financial integration for cohabiting non-parents. Relatedly, about $51 \%$ of respondents would be predicted to indicate married parents should ideally withhold at least some income from the common pot (.10 separate-only plus .40 for partial-pooling).

I now turn to analyzing the extent of ideal financial integration among the sub-sample of respondents who selected the partial-pooling option (45\% of respondents). I used ordinary least squares regression models to evaluate preferred differences in the amount of income distributed between shared and individual accounts. Table 4 shows the preferred degree of income sharing was greater when couples were shown as parents and in formally legalized relationships. The average increase in preferred earnings shared was .09 for married parents compared with cohabiting non-parents, holding all the other model variables constant at their mean. Table 4 shows negative and statistically significant coefficients of the marital and parental status 
manipulations associated with "His Account" and "Her Account," indicating ideals about income are responsive to family transitions. As men and women become husbands and wives and fathers and mothers, the proportion of shared income ideally increases.

[Insert Table 4 about here]

Figure 3 illustrates the average predicted proportion of earned income to be distributed into each account when holding the other model variables at their mean (calculated from Table 4). For example, the predicted proportion of income that these respondents reported married parents should keep in a shared account was $62 \%$, holding the other variables at their mean. In contrast, the ideal level of sharing for cohabiting non-parents reported by the sample of respondents who selected this partial-pooling arrangement was .52. Men ideally withhold $23 \%$ of their earnings for personal use when cohabiting without children, but only $19 \%$ of their earnings if they are an unwed parent or married without children $(\mathrm{p}<.05)$. Beliefs about women's personal finances seem to be influenced in the same way. Statistical tests indicate no statistical difference between the proportion of total household income deposited into "His" and "Her" accounts within marital and parental vignette conditions.

[Insert Figure 3 about here]

Turning now to the relative income vignette manipulation, I found no difference in perceptions of the amount of shared income between the man primary-earner vignette compared with the equal-earning vignette, but significantly less sharing of income when women were presented as the primary earner. Table 4 shows statistically significant differences in earning distributions in "His" and "Her" individual accounts for each of the relative earnings categories. As expected, respondents reported the higher earner, regardless of gender, should have more individual money, reflecting their earnings advantage in the marketplace. The lower earner was similarly 
disadvantaged in personal autonomy over income. For example, holding the other variables at their means, women were expected to have $13 \%$ of the total household earnings in their personal account under men as primary-earner conditions compared with $33 \%$ of the total earnings when women were the primary earners themselves (see Figure 4). When women were the primaryearner, the predicted portion of the total earnings in their own accounts was proportionally higher $(33 \%)$ compared with men's $(28 \%)$ when they were presented as the primary earner $(\mathrm{p}<.05)$. Contrary to hypotheses that beliefs in economic autonomy would be intertwined with notions of men providing for their families, women's higher earnings were associated with a greater commitment to economic autonomy. These patterns potentially indicate respondents believe that the way for women to ensure control over their finances is to withhold a greater proportion of their earnings from the common pot. With one exception, interaction models of marital and parental status by relative earnings indicated that ideology about economic autonomy did not operate at a lesser degree as perceptions of family unity increased. When women were presented as the primary earners and married, the amount women were expected to keep in their personal account was slightly decreased (analysis not shown).

[Insert Figure 4 about here]

\section{DISCUSSION AND CONCLUSIONS}

Differentiating between trends in the instability of families, individualized relationships, and movement towards gender equality has been difficult when analyzing couples' behavior. This research addresses this gap by empirically investigating the normative beliefs behind the ways money is allocated within families. I began by reviewing the predictions of preferences for how money should ideally be allocated by taking three perspectives in turn. First, from the perspective that increasing disintegration of money in families is a signal of rising family 
instability, couples viewed as the most committed should be more likely to be seen as fully integrating their financial resources as the preferred option. In contrast, from a perspective that relationships are becoming more individualized, the prevalence of preferences for couples to withhold money from a common pot should be universal. Third, I offered competing predictions about how gender may alter commitment to principles of economic autonomy. On the one hand, because primary earning is intertwined with masculinity, when women are presented as the higher earner there may not be agreement that higher-earning individuals are entitled to more personal spending money. On the other hand, when women are primary earners, ideals of economic autonomy may be called upon as a tactic to ensure women maintain control over their earnings.

In the vignette scenarios I tested, a greater proportion of survey respondents expected married couples to have only shared accounts compared with preferences for cohabitors, consistent with predictions that signals of relationship investment correspond with greater support for integration of couples' finances. Still, about half of the sample evaluated married couples as ideally withholding some or all of their earnings from a shared account. Analysis of the sub-sample of respondents who selected the partial-pooling approach showed the predicted proportion of shared earnings was greater than $50 \%$ of total household income for all vignette couples. Taken together, while these results show statistically significantly different levels of financial integration by marital and parental status, they do not show compelling evidence that the ideal level of integration for couples varies substantially by marital and parental status.

These findings suggest researchers should be cautious about interpreting the decision to withhold money from the common family pot as indicative of rising family instability. Instead, these results are consistent with theories of movement towards individualized relationships 
(Lauer \& Yodanis, 2011; Yodanis \& Lauer, 2014). Regardless of legal and blood ties, most people support some level of financial autonomy within relationships. These results also suggest cohabiting parents' integration of finances may be more than a strategy to counter economic burdens, as suggested by previous scholarship (Addo, 2014). A lack of significance in the interaction between marital status and relative earnings in predicting ideals of financial integration may also suggest a departure from earlier research showing the pathways to relationship stability differed by marital status (Brines \& Joyner, 1999). Attitudes about ideal allocation methods differed by respondents' background, suggesting normative beliefs may vary systematically by demographic characteristics.

Arguments that cohabiting is less stable than marriage in part because of a lack of fully integrated resources may be flawed; the majority of survey respondents favored at least some financial integration, no matter the fictional couple's marital or parental status. These findings diverge from predictions that only couples at risk of exiting their relationship pursue economic autonomy. In its place, an underlying commitment to autonomy within stable partnerships may be a function of the transition to individualized relationships. This perception may also reflect recognition of the efficiencies of income pooling, even in relationships without legal protection (Treas, 1993). These findings underscore the need to consider individualist interests within all types of family units.

Attention to who earned the money was influential on how income was expected to be distributed within families. Higher relative earners were evaluated as having greater entitlements to personal earnings - money which can presumably be spent autonomously. These results are consistent with evidence that perceived ownership of income is a primary consideration in how couples distribute financial resources (Burgoyne, Reibstein, Edmunds, \& Dolman, 2007), which 
may be one reason why women's increasing labor force participation has not been a sufficient condition to bring about equality within families. Although men's and women's time in paid and unpaid labor has converged (Sayer, 2005), economic power within families continues to favor men, in part because of their greater earnings in the labor market (Lyngstad et al., 2011).

Support for withholding earnings from the common pot was slightly larger in magnitude for higher-earning women than for higher-earning men, potentially suggesting women's empowerment through the pursuit of self-determination rather than a drive towards earnings equality. Men and women in this study seem to be in agreement that women's earnings should be treated differently from men's earnings. Women may withhold their increased earnings to ensure control over them, maybe to direct money towards services that replace their unpaid household burdens (Cohen, 1998; Gupta, 2007). These findings are consistent with other research that questions gender-neutral exchange approaches to explain power dynamics within heterosexual relationships (Bittman, England, Sayer, Folbre, \& Matheson, 2003; Munsch, 2015).

This study is not without its limitations. I used a shared account as a proxy for collective ownership, but this is an untested assumption. A joint bank account may reflect ideals of collective operation, but behavioral research suggests that is not always the reality (Burgoyne et al., 2006). Additionally, this study explores attitudes about allocation of money within families, but it cannot determine how these beliefs translate into behavior. The results point to the ways couples confront contradictions in their relationship, but the dynamics of how couples negotiate these competing values cannot be determined using this research design. This study was also limited to analysis of heterosexual couples, as the anticipated variance in gendered dynamics in lesbian and gay relationships would have introduced additional factors beyond its scope. To limit the experiment to a feasible number of vignette conditions, the study did not attempt to 
manipulate the perceived race or ethnicity of the fictional couples, which may have led to differences in perceptions of the survey variables. Further variations of these characteristics-as well as altering the relationship duration, household income, relative earnings, ages, and inclusion of portrayals of step-families - could be an important extension of this research.

These findings add to evidence that power differentials in couples are not fully explained by income differentials, and identity and family formation processes are important dimensions to investigate (Moore, 2008). Equality and autonomy exist in tension with each other; women's financial autonomy may not lead to equality and in some ways may impede it (Elizabeth, 2001). Notably, compared with male respondents, female respondents were slightly more likely to select a partial-pooling approach as opposed to a pooling-only model for the fictional couples, but I found no gender difference in the preferred degree of financial integration among the respondents who selected the partial-pooling model. It is possible that women might be gaining normative support for converting their earnings into power within the family, so long as they retain autonomous control over that income. Another possible next step would be to investigate the impact of allocation systems on the stability of relationships and the well-being of each individual in the event of relationship dissolution. A secondary finding revealed that higherearning respondents were less likely to select separate accounts in the vignettes compared with lower-earning participants, regardless of the fictional couple's relative earnings or their marital or parental status. Investigating the ways class location informs how couples negotiate tensions between commitments to financial autonomy and family unity may be other important avenues for future investigation.

In summary, these findings challenge conventional wisdom that a benefit of marriage over cohabitation is that marriage uniquely increases the sharing of resources within families. 
Respondents endorsed high levels of, but not complete, financial integration for cohabitors and married couples alike. Cohabiting couples were evaluated as preferably integrating resources despite the lack of laws outlining their obligations to one another in the event of a break-up. These findings suggest marital laws trail behind cultural norms about resource sharing within families. Social policies that assume cohabiting couples do not combine their income are likely out of sync with how couples experience their own relationships. Findings from this study add to evidence that cohabiting couples could be categorized as families, similar to married couples, for government purposes such as in welfare policies and measurements of poverty (Kenney, 2004). They are also consistent with evidence suggesting the pursuit of financial autonomy is a relevant issue for welfare reform (Bennett \& Sung, 2013).

Similarly, married couples were viewed as less of a collective economic unit than most marital and divorce laws presume. Thus, policy efforts to mitigate women's poverty by encouraging them to marry may be unlikely to substantially increase women's financial resources, if the attitudes found in this study reflect behavior. Family policies encouraging poor women to marry may rely on faulty assumptions that people are motivated to redistribute unequal earnings in the labor market within married families. Rather, this evidence suggests couples draw on beliefs in economic autonomy and entitlement to individual earnings when allocating financial resources, likely perpetuating unequal market forces within personal relationships. Increasing women's absolute earnings in the marketplace may have a more substantial impact on women's access to financial resources than encouraging them to seek financial stability through courtship and marriage. 
Money in Families

\section{REFERENCES}

Addo, F. R. (2014). Debt, Cohabitation, and Marriage in Young Adulthood. Demography, 51(5), 1677-1701.

Addo, F. R. (2017). Financial Integration and Relationship Transitions of Young Adult Cohabiters. Journal of Family and Economic Issues, 38(1), 84-99.

Addo, F. R., \& Sassler, S. (2010). Financial Arrangements and Relationship Quality in LowIncome Couples. Family Relations, 59(4), 408-423.

Ashby, K. J., \& Burgoyne, C. B. (2008). Separate financial entities?: Beyond categories of money management. The Journal of Socio-Economics, 37(2), 458-480.

Ashby, K. J., \& Burgoyne, C. B. (2009). The financial practices and perceptions behind separate systems of household financial management. The Journal of Socio-Economics, 38(3), 519-529.

Barlow, A. (2008). Cohabiting Relationships, Money and Property: The Legal Backdrop. The Journal of Socio-Economics, 37(2), 502-518.

Belch, M. A., \& Willis, L. A. (2002). Family decision at the turn of the century: has the changing structure of households impacted the family decision-making process? Journal of Consumer Behaviour, 2(2), 111-124.

Bellah, R. N., Madsen, R., Sullivan, W. M., Swidler, A., \& Tipton, S. M. (2008). Habits of the Heart: Individualism and Commitment in American Life. Berkeley, CA: University of California Press.

Bennett, F. (2013). Researching Within-Household Distribution: Overview, Developments, Debates, and Methodological Challenges. Journal of Marriage and Family, 75(3), 582597.

Bennett, F., \& Sung, S. (2013). Dimensions of Financial Autonomy in Low-/Moderate-Income Couples from a Gender Perspective and Implications for Welfare Reform. Journal of Social Policy, 42(4), 701-719.

Bertrand, M., Kamenica, E., \& Pan, J. (2015). Gender Identity and Relative Income within Households. The Quarterly Journal of Economics, 130(2), 571-614.

Bisdee, D., Daly, T., \& Price, D. (2013). Behind Closed Doors: Older Couples and the Gendered Management of Household Money. Social Policy and Society, 12(1), 163-174.

Bittman, M., England, P., Sayer, L. C., Folbre, N., \& Matheson, G. (2003). When Does Gender Trump Money? Bargaining and Time in Household Work. American Journal of Sociology, 109(1), 186-214.

Blood, R. O., \& Wolfe, D. M. (1960). Husbands \& Wives: The Dynamics of Married Living. Glencoe, IL: Free Press.

Blumstein, P., \& Schwartz, P. (1983). American Couples: Money, Work, Sex. New York: William Morrow \& Co. 
Brines, J., \& Joyner, K. (1999). The Ties That Bind: Principles of Cohesion in Cohabitation and Marriage. American Sociological Review, 64(3), 333-355.

Brooks-Gunn, J., Garfinkel, I., McLanahan, S. S., \& Paxson, C. (2011). Fragile Families and Child Wellbeing Study [Public Use Data]. ICPSR31622-v1. Ann Arbor, MI: Interuniversity Consortium for Political and Social Research [distributor]. Retrieved from http://doi.org/10.3886/ICPSR31622.v1

Bumpass, L., \& Lu, H.-H. (2000). Trends in cohabitation and implications for children's family contexts in the United States. Population Studies, 54(1), 29-41.

Burgoyne, C. B. (1990). Money in Marriage: How Patterns of Allocation both Reflect and Conceal Power. Sociological Review, 38(4), 634-665.

Burgoyne, C. B. (2004). Heart-Strings and Purse-Strings: Money in Heterosexual Marriage. Feminism \& Psychology, 14(1), 165-172.

Burgoyne, C. B. (2008). Introduction: Special issue on the household economy. The Journal of Socio-Economics, 37(2), 455-457.

Burgoyne, C. B., Clarke, V., Reibstein, J., \& Edmunds, A. (2006). “All my worldly goods I share with you"? Managing money at the transition to heterosexual marriage. The Sociological Review, 54(4), 619-637.

Burgoyne, C. B., \& Lewis, A. (1994). Distributive justice in marriage: Equality or equity? Journal of Community \& Applied Social Psychology, 4(2), 101-114.

Burgoyne, C. B., \& Morison, V. (1997). Money in Remarriage: Keeping Things Simple - and Separate. The Sociological Review, 45(3), 363-395.

Burgoyne, C. B., Reibstein, J., Edmonds, A. M., \& Routh, D. A. (2010). Marital Commitment, Money and Marriage Preparation: What Changes After the Wedding? Journal of Community \& Applied Social Psychology, 20(5), 390-403.

Burgoyne, C. B., Reibstein, J., Edmunds, A., \& Dolman, V. (2007). Money Management Systems in Early Marriage: Factors Influencing Change and Stability. Journal of Economic Psychology, 28(2), 214-228.

Burns, M., Burgoyne, C. B., \& Clarke, V. (2008). Financial Affairs? Money Management in Same-Sex Relationships. The Journal of Socio-Economics, 37(2), 481-501.

Catlett, B. S., \& McKenry, P. C. (1996). Implications of Feminist Scholarship for the Study of Women's Postdivorce Economic Disadvantage. Family Relations, 45(1), 91-97.

Cherlin, A. J. (2004). The Deinstitutionalization of American Marriage. Journal of Marriage and Family, 66(4), 848-861.

Cherlin, A. J. (2009). How American Family Life is Different. In The Marriage-Go-Round: The State of Marriage and the Family in America Today. New York: Alfred A. Knopf.

Cohen, P. N. (1998). Replacing Housework in the Service Economy: Gender, Class, and RaceEthnicity in Service Spending. Gender \& Society, 12(2), 219-231. 
Cohen, P. N. (2014). The Family: Diversity, Inequality, and Social Change. New York: W. W. Norton \& Company.

Coltrane, S. (1996). Family Man: Fatherhood, Housework and Gender Equity. New York: Oxford University Press.

Coontz, S. (2005). Marriage, a History: How Love Conquered Marriage. New York: Penguin Books.

Copp, J. E., Giordano, P. C., Manning, W. D., \& Longmore, M. A. (2016). Couple-Level Economic and Career Concerns and Intimate Partner Violence in Young Adulthood. Journal of Marriage and Family, 78(3), 744-758.

DeNavas-Walt, C., \& Proctor, B. D. (2015). Income and Poverty in the United States: 2014 (Current Population Reports) (pp. 60-252). Washington, D.C: U.S. Census Bureau. Retrieved from https://www.census.gov/content/dam/Census/library/publications/2015/demo/p60252.pdf

Desai, S. (1992). Children at Risk: The Role of Family Structure in Latin America and West Africa. Population and Development Review, 18(4), 689-717.

Edin, K., \& Nelson, T. J. (2013). Doing the Best I Can: Fatherhood in the Inner City. Berkeley: University of California Press.

Elizabeth, V. (2001). Managing Money, Managing Coupledom: A Critical Examination of Cohabitants' Money Management Practices. The Sociological Review, 49(3), 389-411.

Ferree, M. M. (1990). Beyond Separate Spheres: Feminism and Family Research. Journal of Marriage and Family, 52(4), 866-884.

Freese, J., \& Druckman, J. (2016). Data collected by Time-sharing Experiments for the Social Sciences, NSF Grant 0818839. Principal Investigators.

Gerson, K. (2009). Changing Lives, Resistant Institutions: A New Generation Negotiates Gender, Work, and Family Change. Sociological Forum, 24(4), 735-753.

Gibson-Davis, C. M., Edin, K., \& McLanahan, S. (2005). High Hopes but Even Higher Expectations: The Retreat From Marriage Among Low-Income Couples. Journal of Marriage and Family, 67(5), 1301-1312.

Goldstein, J. R., \& Kenney, C. T. (2001). Marriage Delayed or Marriage Forgone? New Cohort Forecasts of First Marriage for U.S. Women. American Sociological Review, 66(4), 506519.

Goodwin, P. Y., Mosher, W. D., \& Chandra, A. (2010). Marriage and Cohabitation in the United States: A Statistical Portrait Based on Cycle 6 (2002) of the National Survey of Family Growth. In Vital Health Statistics (Vol. 23). Hyattsville, MD: National Center for Health Statistics.

Gupta, S. (2007). Autonomy, Dependence, or Display? The Relationship between Married Women's Earnings and Housework. Journal of Marriage and Family, 69(2), 399-417. 
Hamplová, D., \& Le Bourdais, C. (2009). One Pot or Two Pot Strategies? Income Pooling in Married and Unmarried Households in Comparative Perspective. Journal of Comparative Family Studies, 40(3), 355-385.

Harris, K. M., Halpern, C. T., Whitsel, E., Hussey, J., Tabor, J., Entzel, P., \& Udry, J. R. (2009). The National Longitudinal Study of Adolescent to Adult Health: Research Design. Retrieved from http://www.cpc.unc.edu/projects/addhealth/design.

Hausman, J., \& McFadden, D. (1984). Specification Tests for the Multinomial Logit Model. Econometrica, 52(5), 1219-1240.

Hochschild, A. R., \& Machung, A. (1989). The Second Shift. New York: Penguin Books.

ISSP Research Group. (2014). Family and Changing Gender Roles IV Variable Report. GESIS Leibniz Institute for the Social Sciences Unter Sachsenhausen.

Kamp Dush, C. M. (2011). Relationship-Specific Investments, Family Chaos, and Cohabitation Dissolution Following a Nonmarital Birth. Family Relations, 60(5), 586-601.

Kenney, C. T. (2004). Cohabiting Couple, Filing Jointly? Resource Pooling and U.S. Poverty Policies. Family Relations, 53(2), 237-247.

Kenney, C. T. (2006). The Power of the Purse: Allocative Systems and Inequality in Couple Households. Gender \& Society, 20(3), 354-381.

Knudsen, K., \& Wærness, K. (2009). Shared or separate? Money management and changing norms of gender equality among Norwegian couples. Community, Work \& Family, 12(1), $39-55$.

Lauer, S. R., \& Yodanis, C. (2011). Individualized Marriage and the Integration of Resources. Journal of Marriage and Family, 73(3), 669-683.

Lieberson, S. (2000). A Matter of Taste: How Names, Fashions, and Culture Change. New Haven: Yale University Press.

Lundberg, S., \& Pollak, R. A. (2014). Cohabitation and the Uneven Retreat from Marriage in the U.S., 1950-2010. In L. P. Boustan, C. Frydman, \& R. A. Margo (Eds.), Human Capital in History: The American Record (pp. 241-272). Chicago, IL: University Of Chicago Press.

Lyngstad, T. H., Noack, T., \& Tufte, P. A. (2011). Pooling of Economic Resources: A Comparison of Norwegian Married and Cohabiting Couples. European Sociological Review, 27(5), 624-635.

Manning, W. D. (2013). Trends in Cohabitation: Over Twenty Years of Change, 1987-2010 (No. FP-13-12). Bowling Green State University: National Center for Family \& Marriage Research. Retrieved from http://ncfmr.bgsu.edu/pdf/family_profiles/file130944.pdf

Manning, W. D., \& Smock, P. J. (2002). First Comes Cohabitation and then Comes Marriage? A Research Note. Journal of Family Issues, 23(8), 1065-1087.

Maxwell, S. E., \& Delaney, H. D. (2004). Designing Experiments and Analyzing Data: A Model Comparison Perspective (2nd ed.). Mahwah, NJ: Lawrence Erlbaum Associates. 
Milkie, M. A., Bianchi, S. M., Mattingly, M. J., \& Robinson, J. P. (2002). Gendered Division of Childrearing: Ideals, Realities, and the Relationship to Parental Well-Being. Sex Roles, 47(1), 21-38.

Moore, M. R. (2008). Gendered Power Relations among Women: A Study of Household Decision Making in Black, Lesbian Stepfamilies. American Sociological Review, 73(2), $335-356$.

Munsch, C. L. (2015). Her Support, His Support: Money, Masculinity, and Marital Infidelity. American Sociological Review, 80(3), 469-495.

Mutz, D. C. (2011). Population-Based Survey Experiments. Princeton, N.J.: Princeton University Press.

Nyman, C., \& Reinikainen, L. (2007). Elusive Independence in a Context of Gender Equality in Sweden. In J. Stocks, C. Diaz, \& B. Hallerod (Eds.), Modern Couples Sharing Money, Sharing Life (pp. 41-71). Basingstoke, UK: Palgrave Macmillan.

Oropesa, R. S., \& Landale, N. S. (2005). Equal access to income and union dissolution among mainland Puerto Ricans. Journal of Marriage and Family, 67(1), 173-190.

Oropesa, R. S., Landale, N. S., \& Kenkre, T. (2003). Income Allocation in Marital and Cohabiting Unions: The Case of Mainland Puerto Ricans. Journal of Marriage and Family, 65(4), 910-926.

Pahl, J. (1989). Money and Marriage. Basingstoke: Palgrave Macmillan.

Pahl, J. (1995). His Money, Her Money: Recent Research on Financial Organisation in Marriage. Journal of Economic Psychology, 16(3), 361-376.

Pahl, J. (2005). Individualisation in Couple Finances: Who Pays for the Children? Social Policy and Society, 4(4), 381-391.

Pedulla, D. S., \& Thébaud, S. (2015). Can We Finish the Revolution? Gender, Work-Family Ideals, and Institutional Constraint. American Sociological Review, 80(1), 116-139.

Ridgeway, C. L. (2011). Framed by Gender: How Gender Inequality Persists in the Modern World. New York: Oxford University Press.

Romo, L. K. (2014). “These Aren’t Very Good Times”: Financial Uncertainty Experienced by Romantic Partners in the Wake of an Economic Downturn. Journal of Family and Economic Issues, 35(4), 477-488.

Sayer, L. C. (2005). Gender, Time and Inequality: Trends in Women's and Men's Paid Work, Unpaid Work and Free Time. Social Forces, 84(1), 285-303.

Schoen, R., \& Cheng, Y. A. (2006). Partner Choice and the Differential Retreat from Marriage. Journal of Marriage and Family, 68(1), 1-10.

Schwartz, P. (1994). Love Between Equals: How Peer Marriage Really Works. New York: Free Press. 
Smock, P. J. (2000). Cohabitation in the United States: An Appraisal of Research Themes, Findings, and Implications. Annual Review of Sociology, 26, 1-20.

Spain, D., \& Bianchi, S. M. (1996). Balancing Act: Motherhood, Marriage, and Employment Among American Women. New York: Russell Sage Foundation.

Stepler, R. (2017, April 6). Number of U.S. Adults Cohabiting with a Partner Continues to Rise, Especially Among those 50 and Older. Retrieved from http://www.pewresearch.org/facttank/2017/04/06/number-of-u-s-adults-cohabiting-with-a-partner-continues-to-riseespecially-among-those-50-and-older/

Swidler, A. (1986). Culture in Action: Symbols and Strategies. American Sociological Review, 51(2), 273-286.

Tichenor, V. J. (1999). Status and Income as Gendered Resources: The Case of Marital Power. Journal of Marriage and Family, 61(3), 638-650.

Townsend, N. (2002). Package Deal: Marriage, Work And Fatherhood In Men's Lives. Philadelphia: Temple University Press.

Treas, J. (1993). Money in the Bank: Transaction Costs and the Economic Organization of Marriage. American Sociological Review, 58(5), 723-734.

Treas, J., \& Widmer, E. (2000). Whose Money? Financial Management in Marriage: A multilevel analysis for 23 countries. In W. Raub \& J. Weesie (Eds.), The management of durable relations: Theoretical and empirical models for households and organizations (pp. 44-45). Amsterdam: Thela Thesis.

Vaisey, S. (2009). Motivation and Justification: A Dual-Process Model of Culture in Action. American Journal of Sociology, 114(6), 1675-1715.

Vogler, C. (2005). Cohabiting Couples: Rethinking Money in the Household at the Beginning of the Twenty First Century. The Sociological Review, 53(1), 1-29.

Vogler, C., Brockmann, M., \& Wiggins, R. D. (2006). Intimate relationships and changing patterns of money management at the beginning of the twenty-first century. The British Journal of Sociology, 57(3), 455-482.

Vogler, C., Brockmann, M., \& Wiggins, R. D. (2008). Managing money in new heterosexual forms of intimate relationships. The Journal of Socio-Economics, 37(2), 552-576.

Vogler, C., \& Pahl, J. (1994). Money, Power and Inequality within Marriage. Sociological Review, 42(2), 263-288. doi:10.1111/1467-954X.ep9407143246

Yodanis, C., \& Lauer, S. (2014). Is Marriage Individualized? What Couples Actually Do. Journal of Family Theory \& Review, 6(2), 184-197.

Zelizer, V. A. (1989). The Social Meaning of Money: "Special Monies." American Journal of Sociology, 95(2), 342-377. 


\section{TABLES}

Table 1. Weighted Descriptive Statistics of Respondent Characteristics

\begin{tabular}{|c|c|c|}
\hline Variable & Description & $\begin{array}{r}\text { Proportion/ } \\
\text { Mean }\end{array}$ \\
\hline Woman & Female respondent $(1=$ Yes $)$ & 0.52 \\
\hline \multicolumn{3}{|l|}{ Relationship Status } \\
\hline Married & Respondent is married ( $1=$ Yes $)$ & 0.53 \\
\hline Cohabiting & Respondent is living with a partner $(1=$ Yes $)$ & 0.05 \\
\hline Never married & $\begin{array}{l}\text { Respondent reports they have never been } \\
\text { married }(1=\text { Yes })\end{array}$ & 0.25 \\
\hline Other relationship status & $\begin{array}{l}\text { Respondent reports they are divorced, } \\
\text { separated, or widowed }(1=\text { Yes })\end{array}$ & 0.16 \\
\hline Parent & $\begin{array}{l}\text { At least one child lives with the respondent } \\
(1=\text { Yes })\end{array}$ & 0.29 \\
\hline White & White respondent (vs non-white) $(1=$ Yes $)$ & 0.65 \\
\hline \multicolumn{3}{|l|}{ Education } \\
\hline Less than high school & $\begin{array}{l}\text { Respondent's highest degree received is less } \\
\text { than a high school diploma }(1=\text { Yes })\end{array}$ & 0.12 \\
\hline High school & $\begin{array}{l}\text { Respondent's highest degree received is a } \\
\text { high school diploma }(1=\text { Yes })\end{array}$ & 0.58 \\
\hline College & $\begin{array}{l}\text { Respondent's highest degree received is at } \\
\text { least a bachelor's degree ( } 1=\text { Yes })\end{array}$ & 0.30 \\
\hline Employed & $\begin{array}{l}\text { Respondent reports they are working } \\
(1=\text { Yes })\end{array}$ & 0.59 \\
\hline Income & $\begin{array}{l}\text { Respondent's household income is at least } \\
\$ 50,000 \text { a year }(1=\text { Yes })\end{array}$ & 0.62 \\
\hline Age & Respondent's age in years (18 to 92 ) & $\begin{array}{l}47.20 \\
(17.38)\end{array}$ \\
\hline
\end{tabular}

$\mathrm{N}=3,986$; Sample descriptives are weighted; Standard deviations in parentheses for continuous variables. 
Table 2. Descriptive Statistics of Weighted Dependent Measures by Vignette Manipulation

\begin{tabular}{|c|c|c|c|c|c|c|c|c|}
\hline & \multicolumn{3}{|c|}{ Marital Status } & \multicolumn{2}{|c|}{ Parental Status } & \multicolumn{3}{|c|}{ Relative Earnings } \\
\hline & All & Cohabit & Married & Child Free & Parent & $\begin{array}{c}\text { Man } \\
\text { Primary } \\
\text { Earner }\end{array}$ & $\begin{array}{c}\text { Woman } \\
\text { Primary Earner }\end{array}$ & $\begin{array}{c}\text { Equal } \\
\text { Earners }\end{array}$ \\
\hline \multicolumn{9}{|c|}{ Organizational Strategy $(\mathrm{N}=3,986)$} \\
\hline Shared & $\begin{array}{c}0.39 \\
(0.49)\end{array}$ & $\begin{array}{c}0.30 \\
(0.46)\end{array}$ & $\begin{array}{l}0.48^{a} \\
(0.50)\end{array}$ & $\begin{array}{c}0.37 \\
(0.48)\end{array}$ & $\begin{array}{l}0.42^{b} \\
(0.49)\end{array}$ & $\begin{array}{c}0.41 \\
(0.49)\end{array}$ & $\begin{array}{c}0.40 \\
(0.49)\end{array}$ & $\begin{array}{l}0.37^{\mathrm{c}} \\
(0.48)\end{array}$ \\
\hline Separate & $\begin{array}{c}0.17 \\
(0.37)\end{array}$ & $\begin{array}{c}0.23 \\
(0.42)\end{array}$ & $\begin{array}{l}0.11^{a} \\
(0.31)\end{array}$ & $\begin{array}{c}0.21 \\
(0.41)\end{array}$ & $\begin{array}{l}0.12^{b} \\
(0.33)\end{array}$ & $\begin{array}{c}0.18 \\
(0.38)\end{array}$ & $\begin{array}{c}0.16 \\
(0.37)\end{array}$ & $\begin{array}{c}0.16 \\
(0.36)\end{array}$ \\
\hline Partial-Pooling & $\begin{array}{c}0.44 \\
(0.50)\end{array}$ & $\begin{array}{c}0.47 \\
(0.50)\end{array}$ & $\begin{array}{l}0.41^{a} \\
(0.49)\end{array}$ & $\begin{array}{c}0.43 \\
(0.49)\end{array}$ & $\begin{array}{c}0.46 \\
(0.50)\end{array}$ & $\begin{array}{c}0.41 \\
(0.49)\end{array}$ & $\begin{array}{c}0.44 \\
(0.50)\end{array}$ & $\begin{array}{l}0.47^{\mathrm{c}} \\
(0.50)\end{array}$ \\
\hline \multicolumn{9}{|c|}{ Distribution of Earnings $(\mathrm{N}=1,784)$} \\
\hline His Account & $\begin{array}{c}0.20 \\
(0.12)\end{array}$ & $\begin{array}{c}0.21 \\
(0.12)\end{array}$ & $\begin{array}{l}0.18^{a} \\
(0.13)\end{array}$ & $\begin{array}{c}0.21 \\
(0.13)\end{array}$ & $\begin{array}{l}0.19^{b} \\
(0.12)\end{array}$ & $\begin{array}{c}0.28 \\
(0.15)\end{array}$ & $\begin{array}{c}0.11^{c} \\
(0.06)\end{array}$ & $\begin{array}{l}0.20^{\mathrm{cd}} \\
(0.09)^{2}\end{array}$ \\
\hline Her Account & $\begin{array}{c}0.22 \\
(0.14)\end{array}$ & $\begin{array}{c}0.23 \\
(0.14)\end{array}$ & $\begin{array}{l}0.21^{a} \\
(0.13)\end{array}$ & $\begin{array}{c}0.23 \\
(0.13)\end{array}$ & $\begin{array}{c}0.22 \\
(0.14)\end{array}$ & $\begin{array}{c}0.13 \\
(0.06)\end{array}$ & $\begin{array}{l}0.33^{\mathrm{c}} \\
(0.15)\end{array}$ & $\begin{array}{l}0.20^{\mathrm{cd}} \\
(0.09)^{2}\end{array}$ \\
\hline Shared Account & $\begin{array}{c}0.58 \\
(0.19) \\
\end{array}$ & $\begin{array}{c}0.56 \\
(0.18) \\
\end{array}$ & $\begin{array}{l}0.60^{\mathrm{a}} \\
(0.19)^{2} \\
\end{array}$ & $\begin{array}{c}0.56 \\
(0.19) \\
\end{array}$ & $\begin{array}{l}0.60^{\mathrm{b}} \\
(0.19) \\
\end{array}$ & $\begin{array}{r}0.59 \\
(0.19) \\
\end{array}$ & $\begin{array}{l}0.55^{\mathrm{c}} \\
(0.19)\end{array}$ & $\begin{array}{l}0.60^{\mathrm{d}} \\
(0.18) \\
\end{array}$ \\
\hline
\end{tabular}

Note: Descriptive statistics include survey weights; Standard deviations in parenthesis;

${ }^{a}$ Significantly different from cohabiting couple vignette $(\mathrm{p}<.05$; two-tailed test).

${ }^{\mathrm{b}}$ Significantly different from child free couple vignette $(\mathrm{p}<.05$; two-tailed test).

${ }^{c}$ Significantly different from male breadwinner couple vignette ( $p<.05$; two-tailed test).

${ }^{\mathrm{d}}$ Significantly different from female breadwinner couple vignette $(\mathrm{p}<.05$; two-tailed test). 
Table 3. Weighted Multinomial Logistic Regression Analysis of Preferred Income Organizational Approaches by Vignette Manipulations and Respondent Characteristics

\begin{tabular}{|c|c|c|c|c|}
\hline & \multicolumn{2}{|c|}{ Partial-Pooling } & \multicolumn{2}{|c|}{ Separate Accounts } \\
\hline & Coef. & $\mathrm{SE}$ & Coef. & SE \\
\hline \multicolumn{5}{|c|}{ Vignette Manipulations } \\
\hline \multicolumn{5}{|c|}{$\begin{array}{l}\text { Marital \& Parental Status } \\
\text { (Reference is Cohabiting w/out Children) }\end{array}$} \\
\hline Cohabiting Parents & -0.21 & $(0.12)$ & -1.12 & $(0.15) * * *$ \\
\hline Married w/out Children & -0.80 & $(0.12) * * *$ & -1.79 & $(0.16) * * *$ \\
\hline Married Parents & -0.83 & $(0.12) * * *$ & -1.86 & $(0.16) * * *$ \\
\hline \multicolumn{4}{|l|}{ Relationship Duration } & $(0.11) * * *$ \\
\hline \multicolumn{5}{|l|}{ Relative Income } \\
\hline Equal Earners & 0.26 & $(0.10) * *$ & -0.01 & $(0.14)$ \\
\hline Woman Primary Earner & 0.12 & $(0.10)$ & -0.05 & $(0.13)$ \\
\hline \multicolumn{5}{|l|}{ Respondent Characteristics } \\
\hline Women & 0.36 & $(0.08) * * *$ & 0.17 & $(0.11)$ \\
\hline \multicolumn{5}{|c|}{ Relationship Status (Reference is married) } \\
\hline Cohabiting & 1.15 & $(0.22) * * *$ & 1.28 & $(0.26) * * *$ \\
\hline Never married & 0.95 & $(0.12) * * *$ & 0.79 & $(0.16) * * *$ \\
\hline Other relationship status & 0.51 & $(0.11) * * *$ & 0.43 & $(0.16) * *$ \\
\hline Parent & 0.05 & $(0.10)$ & -0.07 & $(0.14)$ \\
\hline White & -0.45 & $(0.09) * * *$ & -0.37 & $(0.12) * *$ \\
\hline \multicolumn{5}{|c|}{ Education (Reference is high school) } \\
\hline Less than high school & -0.13 & $(0.16)$ & 0.09 & $(0.20)$ \\
\hline College & 0.25 & $(0.09) * *$ & -0.04 & $(0.13)$ \\
\hline Employed & 0.18 & $(0.09) *$ & 0.14 & $(0.13)$ \\
\hline Income greater than $\$ 50,000$ & -0.13 & $(0.09)$ & -0.33 & $(0.13) * *$ \\
\hline Age & 0.01 & $(0.00) * * *$ & 0.00 & $(0.00)$ \\
\hline Intercept & -0.36 & $(0.29)$ & 0.82 & $(0.38) *$ \\
\hline
\end{tabular}

$\mathrm{N}=3,986$; Note: Baseline is a Shared Account; Standard errors are in parentheses; Listwise deletion used for missing data; $\mathrm{Wald}_{\mathrm{chi}}{ }^{2}=396.89$; Bayesian information criterion $\left(\mathrm{BIC}^{\prime}\right)=7924 ; * \mathrm{p}<.05 ; * * \mathrm{p}<.01 ; * * * \mathrm{p}<.001$ (two-tailed test) 
Table 4. Weighted OLS Regression Analysis of the Effects of Vignette Manipulations and Respondent Characteristics on Perceptions of Allocation of Household Income

\begin{tabular}{|c|c|c|c|c|c|c|}
\hline & \multicolumn{2}{|c|}{ Shared Account } & \multicolumn{2}{|c|}{ His Account } & \multicolumn{2}{|c|}{ Her Account } \\
\hline & Coef. & $\mathrm{SE}$ & Coef. & $\mathrm{SE}$ & Coef. & $\mathrm{SE}$ \\
\hline \multicolumn{7}{|l|}{ Vignette Manipulations } \\
\hline \multicolumn{7}{|c|}{$\begin{array}{l}\text { Marital \& Parental Status } \\
\text { (Reference is Cohabiting w/out Children) }\end{array}$} \\
\hline Cohabiting Parents & 0.06 & $(0.01) * * *$ & -0.04 & $(0.01) * * *$ & -0.02 & $(0.01) * *$ \\
\hline Married w/out Children & 0.07 & $(0.01) * * *$ & -0.03 & $(0.01) * * *$ & -0.04 & $(0.01) * * *$ \\
\hline Married Parents & 0.09 & $(0.01) * * *$ & -0.05 & $(0.01) * * *$ & -0.05 & $(0.01) * * *$ \\
\hline $\begin{array}{l}\text { Relationship Duration } \\
\text { (Reference is } 3 \text { years) }\end{array}$ & 0.01 & $(0.01)$ & 0.00 & $(0.01)$ & 0.00 & $(0.01)$ \\
\hline \multicolumn{7}{|c|}{$\begin{array}{l}\text { Relative Income } \\
\text { (Reference is Man Primary Earner) }\end{array}$} \\
\hline Equal Earners & 0.01 & $(0.01)$ & -0.09 & $(0.01) * * *$ & 0.07 & $(0.00) * * *$ \\
\hline Woman Primary Earner & -0.04 & $(0.01) * *$ & -0.17 & $(0.01) * * *$ & 0.20 & $(0.01) * * *$ \\
\hline \multicolumn{7}{|l|}{ Respondent Characteristics } \\
\hline Women & 0.02 & $(0.01)$ & -0.01 & $(0.01)$ & -0.01 & $(0.01)$ \\
\hline \multicolumn{7}{|l|}{$\begin{array}{l}\text { Relationship Status } \\
\text { (Reference is married) }\end{array}$} \\
\hline Cohabiting & -0.02 & $(0.02)$ & 0.00 & $(0.01)$ & 0.02 & $(0.01)$ \\
\hline Never married & -0.01 & $(0.01)$ & 0.00 & $(0.01)$ & 0.01 & $(0.01)$ \\
\hline Other relationship status & 0.02 & $(0.01)$ & 0.00 & $(0.01)$ & -0.02 & $(0.01) *$ \\
\hline Parent & 0.00 & $(0.01)$ & 0.00 & $(0.01)$ & 0.00 & $(0.01)$ \\
\hline White & 0.04 & $(0.01) * *$ & -0.01 & $(0.01) *$ & -0.02 & $(0.01) * * *$ \\
\hline \multicolumn{7}{|c|}{ Education (Reference is high school) } \\
\hline Less than high school & 0.01 & $(0.02)$ & -0.02 & $(0.01)$ & 0.00 & $(0.01)$ \\
\hline College & 0.01 & $(0.01)$ & 0.00 & $(0.01)$ & 0.00 & $(0.01)$ \\
\hline Employed & 0.01 & $(0.01)$ & 0.00 & $(0.01)$ & 0.00 & $(0.01)$ \\
\hline Income greater than $\$ 50,000$ & 0.04 & $(0.01) * *$ & -0.02 & $(0.01) * *$ & -0.02 & $(0.01) *$ \\
\hline Age & 0.00 & $(0.00) *$ & 0.00 & $(0.00) * *$ & 0.00 & $(0.00)$ \\
\hline Intercept & 0.42 & $(0.03) * * *$ & 0.37 & $(0.02) * * *$ & 0.20 & $(0.02) * * *$ \\
\hline $\mathrm{R}^{2}$ & 0.07 & & 0.33 & & 0.40 & \\
\hline
\end{tabular}

$\mathrm{N}=1,784$; Note: Analysis includes only respondents who selected "both shared and separate accounts." Standard errors are in parentheses; List wise deletion used for missing data; $* \mathrm{p}<.05 ; * * \mathrm{p}<.01 ; * * * \mathrm{p}<.001$ (two-tailed test) 
Money in Families

Figure 1. Experimental Design

\begin{tabular}{ll} 
Condition \#1 & 1. Married \\
Relationship Status & 2. Living together \\
\hline Condition \#2 & 1. No children \\
Parental Status & 2. One child together \\
\hline
\end{tabular}

1. Although they both work about forty hours per week, Anthony earns $\$ 2,800$ a month while Michelle earns \$1,200 a month.

Condition \#3 2. Although they both work about forty hours per week, Michelle earns

Relative Earnings $\$ 2,800$ a month while Anthony earns $\$ 1,200$ a month.

3. They both work about forty hours per week, and each earns $\$ 2,000$ a month.

$\begin{array}{ll}\text { Condition \#4 } & 1.3 \text { years } \\ \text { Relationship } & 2.7 \text { years } \\ \text { Duration } & \end{array}$

Figure 2. Predicted Probability of Each Organizational Category by Marital/Parental Status Vignette Condition

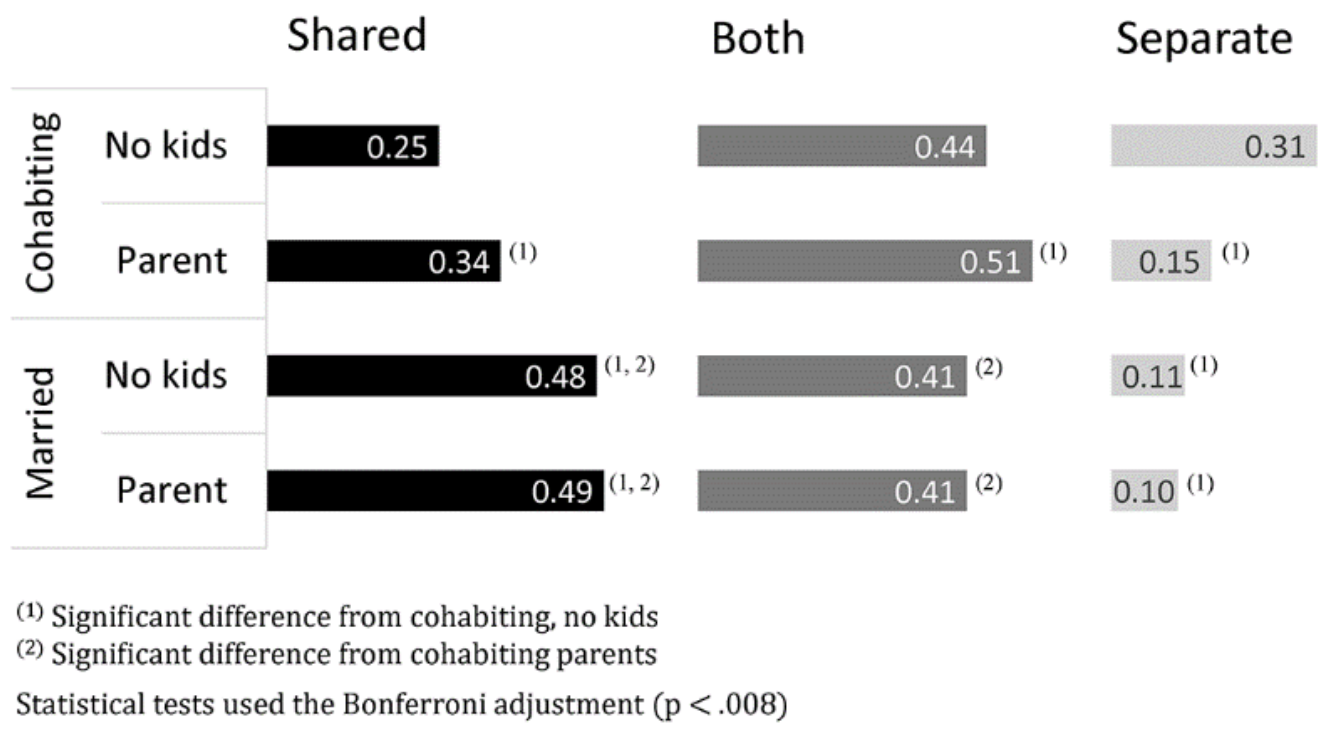


Money in Families

Figure 3. Predicted Ideal Income Distribution by Marital/Parental Status for Partial-Poolers

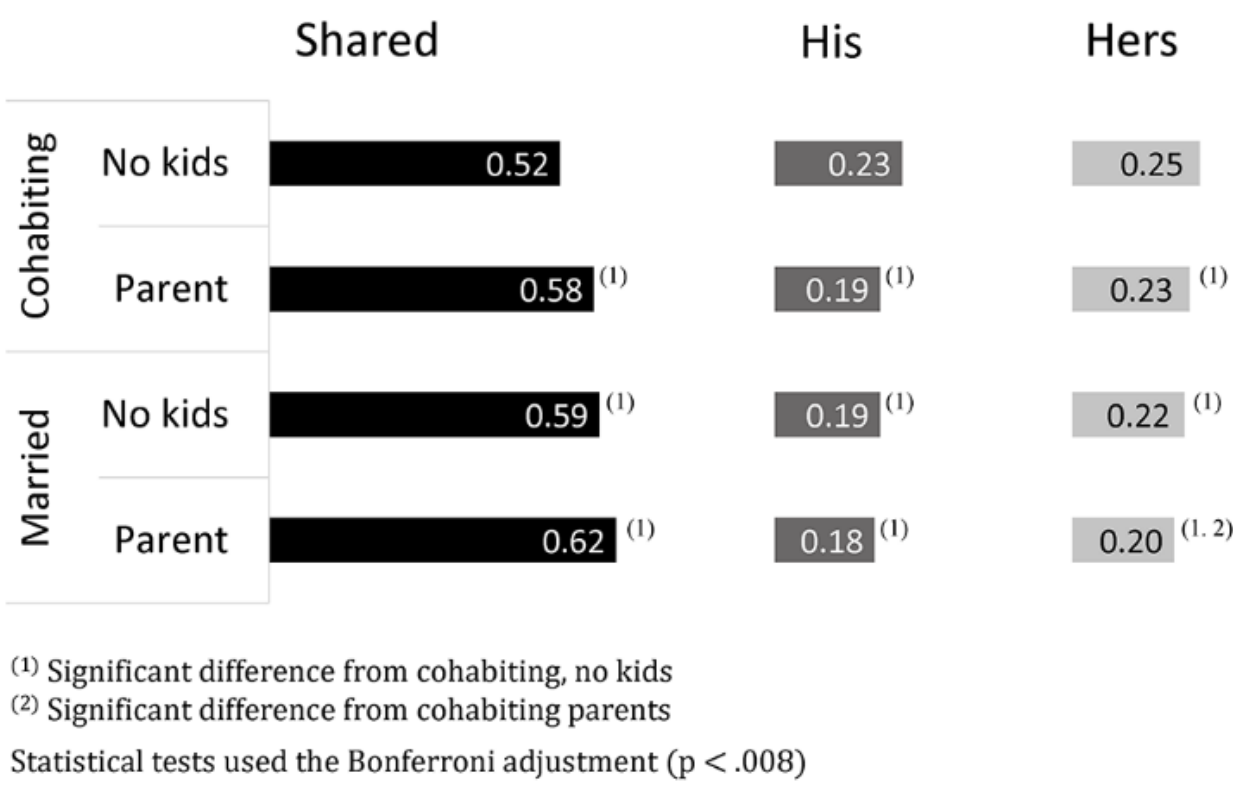

Figure 4. Predicted Probability of Income Distribution by Relative Earnings for Partial-Poolers

\begin{tabular}{|c|c|c|c|}
\hline & Shared & His & Hers \\
\hline Equal earners & 0.60 & 0.20 & 0.20 \\
\hline Man higher-earner & 0.59 & 0.28 & $0.13^{(1)}$ \\
\hline Woman higher-earner & $0.55^{(1.2)}$ & $0.12^{(1.2)}$ & 0.33 \\
\hline
\end{tabular}

